\author{
Ірина Резніченко, \\ кандидат педагогічних наук, \\ старший викладач кафедри виховних \\ технологій та педагогічної творчості \\ Уманського державного педагогічного \\ університету мені Павла Тичини
}

\title{
ФОРМУВАННЯ ПРОФЕСІЙНОЇ КОМПЕТЕНЦІЇ СТУДЕНТІВ ПЕДАГОГІЧНИХ УНІВЕРСИТЕТІВ ЯК ОРГАНІЗАТОРІВ ДИТЯЧОГО ВІДПОЧИНКУ В УМОВАХ ТАБІРНОГО ЛІТА
}

У статті розглядаються етапи формування професійної компетениії студентів педагогічних університетів як організаторів дитячого відпочинку в умовах табірного літа. Охарактеризовано основну мету та завдання виховної роботи в дитячому оздоровчому таборі; розглянуто діяльність студента-практиканта - організатора колективно-творчих справ, конкурсів, які здійснюються на основі самодіяльності, ініціативи, творчого задуму майбутнього фахівия; розкрито можливість $і$ значення курсу «Методика виховної роботи в таборі», практики для ефективної виховної діяльності вожатого в таборі, для формування основних груп компетентностей майбутніх вчителів.

Ключові слова: літній оздоровчий табір, Школа вожатого, літня виховна педагогічна практика, професійна компетениія, педагогиорганізатори.

The article considers the stages of forming the professional competence of students of pedagogical universities as organizers of children's recreation in summer camp conditions. The goal and tasks of educational work in the children's health camp are characterized. It is determined that educational work in the children's health camp includes a reasonable combination of rest, work, sports with cognitive, aesthetic, recreational, game, verbal activities. The content, forms and methods of work are determined by its statute, pedagogical staff and are based on the principles of initiative and initiative of children and students, democracy and humanism, the development of national and culturalhistorical traditions, the priority of universal human spiritual achievements and values.

Besides, the following activities of a student having pedagogical practice at a recreational camp for children have been reviewed in the study: organization of team activity, competitions, concerts, which are carried out on 
the basis of amateur activities, initiative and creative ideas of a future pedagogue. Implementation of the course "Methods of educational work at a camp» as well as pedagogical practice into the educational process of higher educational institutions is extremely important for the formation of future teacher's main competences. Potential of summer educational pedagogical practice in children's health camps influences the formation of all competencies that enable the individual to take an active part in all social spheres, to achieve personal success.

Perspective is the study of the training of students for the organization of children's leisure in different areas of education: civil, labor, aesthetic, physical; development of methodology of pedagogical leadership of students' self-awareness in order to form their personal qualities; study of leadership of out-of-school practice in the interaction of educational institutions with healthimproving.

Key words: summer recreation camp, summer educational pedagogical practice, professional competence, teacher-organizers.

Національна доктрина розвитку освіти у XXI столітті регламентує основні завдання сучасного педагогічного супроводу, серед яких створення умов для розвитку і самореалізації кожної особистості як громадянина України та виховання покоління, здатного навчатися упродовж життя [2].

Впровадження положень доктрини покладено перш за все на шкільні та позашкільні заклади освіти, зокрема і передбачає не тільки пошук інноваційних освітніх технологій, застосування активних методів і прийомів навчання та виховання, які сприяли б формуванню соціальних та особистісних компетенцій дітей, а й посилення практико-орієнтованої підготовки фахівців до реалізації зазначених цілей. Так, підвищення професійної компетенції співробітників різних типів дитячих закладів $\epsilon$ одним з пріоритетних напрямків модернізації освіти.

Повноцінна підготовка висококваліфікованого вчителя має полягати й передбачати також здатність та готовність майбутнього вчителя до позашкільної роботи. Така освіта $є$ важливою складовою системи освіти України й значною мірою сприяс зростанню інтелектуального потенціалу суспільства, всебічному розвитку особистості як найвищої людської цінності.

Проведений нами аналіз наукових джерел показав, що проблема формування професійної компетентності студентів педагогічних університетів досліджувалася вітчизняними (В. А. Адольф, Т. Г. Браже, С. В. Будак, С. Г. Вершловський, М. А. Галагузова, О. В. Добудько, І. Б. Котов, В. Ю. Кричевський, В. І. Маслов, Т. В. Новикова, Р. В. Овчарова, Л. Р. Соломко, Н. В. Харитонова) й зарубіжними (Д. Бритела, С. Джимеза, 
Р. Квасниці, В. Ландшеєр, М. Леннона, П. Мерсера, М. Робінсона та інших) науковцями.

Аналіз власного досвіду роботи у ВНЗ та дослідницького матеріалу доводить, що особливістю роботи педагога-організатора у дитячих оздоровчих таборах $\epsilon$ необхідність перебувати зі школярами з ранку до вечора, проводячи на протязі дня різні за змістом та формою пізнавальні, ігрові, спортивно-масові та фізкультурно-оздоровчі заходи. Таким чином, питання формування професійної компетентності студентів педагогічних університетів в літніх оздоровчих таборах є достатньо актуальним.

Мета статті - визначити етапи формування професійної компетенції студентів педагогічних університетів як організаторів дитячого відпочинку в умовах табірного літа.

Організація літнього відпочинку - один з найважливіших аспектів виховної діяльності. Організована діяльність дітей в літній період дозволяє зробити педагогічний процес безперервним на протязі всього року, адже, на сьогоднішній день дитячий літній оздоровчий табір $\epsilon$ установою, що не тільки здійснює оздоровлення і відпочинок дітей, а й виконує освітню i виховну функцію.

Дитячий оздоровчий табір є позашкільним виховним закладом, що створюється з метою зміцнення здоров'я, організації літнього відпочинку, задоволення інтересів i духовних потреб підлітків, при цьому стратегічними завданнями його діяльності є: здоров' я;

- пропаганда здорового способу життя, формування культури

- забезпечення належних умов для повноцінного оздоровлення та відпочинку дітей, розвитку їх творчих здібностей шляхом проведення занять фізичною культурою, туризмом, правоохоронною та краєзнавчою роботою, суспільно корисною працею, а також на основі добровільного вибору видів діяльності за інтересами, дозвілля тощо [1].

Виховна робота в дитячому оздоровчому таборі включає розумне поєднання відпочинку, праці, спорту 3 пізнавальною, естетичною, оздоровчою, ігровою, словесною діяльністю. Зміст, форми і методи роботи визначаються його статутом, педагогічним колективом і грунтуються на принципах ініціативи i самодіяльності дітей та учнівської молоді, демократії і гуманізму, розвитку національних і культурно-історичних традицій, пріоритетності загальнолюдських духовних досягнень i цінностей. Під час перебування дітей у дитячих закладах оздоровлення та відпочинку створюються умови для розвитку їх внутрішнього потенціалу, творчих здібностей, сприяння формуванню ключових компетенцій, розширення кругозору, інтелектуального збагачення розвитку на основі включення в різноманітну, соціально значиму і особистісно привабливу діяльність, змістовного спілкування та міжособистісних стосунків у 
різновіковому колективі [4]. Тому майбутній педагог-організатор повинен творчо мислити, моделювати виховний процес, бути генератором та реалізатором ідей, впроваджувати нові технології в процес виховання під час літнього відпочинку.

Згідно «Типовим положенням про дитячий заклад оздоровлення та відпочинку» до роботи в дитячих оздоровчих закладах під час канікул можуть залучатися студенти педагогічних, медичних та інших навчальних закладів, які перед початком роботи повинні пройти спеціальну підготовку відповідно до порядку, встановленого Міністерством сім'ї, молоді та спорту України [5].

На нашу думку, процес формування професійної компетенції студентів педагогічних університетів як організаторів дитячого відпочинку в умовах табірного літа повинен складатися з чотирьох основних етапів.

I етап. Засвосння теоретичного курсу дисципліни «Методика виховної роботи в літніх оздоровчих таборах».

Навчальна дисципліна «Методика виховної роботи в ЛОТ» має самостійне призначення i одночасно $\epsilon$ складовою всього навчальновиховного процесу по підготовці педагога-вихователя. Мета навчальної дисципліни полягає у закріпленні теоретичних знань з методики виховної роботи, виробленні вмінь і навичок використовувати різноманітні форми організації виховної, оздоровчої роботи 3 дітьми в літніх таборах, підготовці студентів до педагогічної практики в літніх оздоровчих таборах, формуванні творчої особистості майбутніх педагогів.

Основним завданням дисципліни $\epsilon$ ознайомлення студентів 3 особливостями виховної роботи 3 дітьми; вивчення особливості планування виховної роботи в дитячих оздоровчих закладах, ознайомлення 3 введенням документації щодо ЛОТ, формування і розвиток навички спілкування 3 дітьми та молоддю, засвоєння інноваційних педагогічних технологій організації літнього відпочинку й оздоровлення дітей, поглиблення знання студентів 3 педагогіки та методики виховної роботи, вивчення індивідуально-вікових особливостей вихованців, рівнів розвитку ïx груп, соціальних і природних умов для організації розвиваючої життєдіяльності та змістовного відпочинку дітей у літній період, формування досвіду здорового способу життя та зміцнення здоров'я дітей, формування професійних якостей майбутнього педагога (вибирати найефективніші методи і прийоми колективної та індивідуальної роботи 3 вихованцями).

Основними формами проведення занять поряд із традиційними (лекції, семінари, практикуми) є творчі майстерні, майстер-класи, індивідуальні консультації, ділові й рольові ігри. Крім аудиторної роботи увага приділяється і самостійній роботі студентів. Вона спрямовується на вивчення нормативних документів, що регламентують діяльність дитячих 
оздоровчих закладів України, характеризують завдання загального виховного процесу, ознайомлення з типами існуючих в Україні дитячих оздоровчих закладів, їх основними характеристиками, системами організації виховного процесу, його методичного, кадрового забезпечення, скаутських, пластунських таборувань, спеціалізованих таборувань МОН України та Міністерства України у справах сім’ї, молоді та спорту, нормативно-інструктивними матеріалами щодо кадрового забезпечення виховних систем ЛОТ.

Ще однією формою роботи є підготовка ІНДЗ, яке складається 3 підготовки, оформлення та захисту папки з матеріалами на тему «Виховна робота в літніх оздоровчих таборах».

Зміст папки:

1. Назва загону, емблема, загонова пісня (для зразка).

2. Ігри з детальним описом їх проведення (10 штук).

3. Конкурси з детальним описом їх проведення (10 штук).

4. Плани-конспекти виховних годин з використанням інтерактивних методів навчання (3 штуки).

5. Розробка сценаріїв виховних заходів (3 штуки).

6. Орієнтовний план-сітка на одну зміну.

У кінці курсу дисципліни «Методика виховної роботи в ЛОТ» студенти складають залік.

II. етап. Участь студентів у «Школі педагога-організатора». Оскільки підготовка майбутніх педагогів-організаторів дитячого відпочинку повинна мати якісний і системний характер, відвідування «Школи», на нашу думку, є обов’язковим етапом.

За зразок візьмемо «Школу педагога-організатора» на базі Уманського державного педагогічного університету імені Павла Тичини. Робота розпочинається 3 проведення студентського фестивалю, на якому студенти представляють творчий звіт за підсумками роботи в літніх оздоровчих таборах. На виступ формуються команди зі студентів, які працювали у відповідних таборах. Під час театралізованого виступу команди представляють свою роботу в таборі і обов'язково на завершення проводять масову гру з залом.

Далі робота продовжується 3 проведення ряду науково-практичних семінарів по удосконаленню практичних умінь студентів в рамках роботи 3 дітьми в літніх оздоровчих таборах за участю представників Українського дитячого центру «Молода Гвардія», «Артек-Буковель», «Таємниці цивілізації». До участі в роботі семінарів запрошуються також i представники інших закладів дитячого оздоровлення та відпочинку науковці, викладачі вузу, студентство. Розглядаються такі актуальні теми: «Завдання діяльності ЛОТ», «Здоров’я та безпека життєдіяльності вихованців і працівників ЛОТ», «Діяльність вожатого ЛОТ», «Гра у ЛОТ», 
«Сучасні тенденції молодіжних та дитячих інтересів», «Вікові та психолого-педагогічні особливості вихованців ЛОТ», «Форми роботи вожатого із загоном, КТС» та майстер-класи, які охоплюють важливі питання організаційно-методичної роботи в дитячих оздоровчих закладах, а саме: «Проведення виховного заняття із застосуванням ситуативного навчання», «Стилі спілкування та методика проведення масового заходу в умовах табірного літа», «Формування соціальних компетенцій дитини через ділові та настільні ігри», «Реалізація завдань національнопатріотичного виховання в умовах рекреації», «Розвиток творчості дітей засобами театральної педагогіки», «Актуальні ігро-технології в системі оздоровлення та відпочинку», «Глинотерапія як один 3 напрямків арттерапії в роботі з дітьми».

Такі практичні заняття сприяють поглибленому розумінню специфіки роботи вожатого в дитячих оздоровчих закладах. Це і $є$ своєрідною «родзинкою» навчання. На чотири дні майбутні вожаті занурюються в ігрову форму проведення цікавих занять, під час яких неймовірно швидко випробовують вивчену теоретичну базу на практиці.

До того ж більшість студентів розкривають в собі творчий потенціал під час виконання завдань семінару, що, безсумнівно, сприяє більш ефективній діяльності у ролі вожатого на практиці.

Проведення наступних навчальних занять відбувається у березні квітні на базі університету представниками дитячих оздоровчих таборів УДЦ «Молода Гвардія» та «Артек-Буковель». По завершенню навчання проводиться відбір кращих студентів, які мають змогу продовжити подальше навчання на базах відповідних таборів.

Вся практика існування такої форми підготовки вожатих довела ефективність поставлених перед ним завдань. Студенти, які пройшли підготовку в «Школі вожатого», на практиці виявили себе як креативні особистості, які творчо підходять до вирішення завдань, вміло керують конфліктними ситуаціями, швидше налагоджують особистісний контакт 3 вихованцями.

\section{III етап. Проходження педагогічної практики в ЛОТ.}

Під час педагогічної практики в дитячих таборах інтенсифікується процес професійного становлення майбутнього педагога, його самоосвіти i самовиховання, здійснюється формування рівня професійної готовності та придатності до практичної діяльності. Педагогічна практика в дитячих таборах $є$ важливою для подальшої творчої професійної діяльності майбутніх педагогів i носить виробничо-дослідницький характер, розширює сферу спілкування студентів з дітьми [3].

Саме під час практики всі теоретичні знання студентів переходять у безпосередню практичну діяльність.

Компетенції, якими оволодіває педагог-організатор під час практики 
в ЛОТ поділяються на:

- конструктивні (вміння розробляти творчі виховні справи, ігри, вікторини, конкурси і т.д.);

- організаторські (вміння організовувати життєдіяльність у загоні, роботу групи, власну педагогічну діяльність);

- комунікативні (вміння встановлювати доцільні, доброзичливі стосунки 3 вихованцями, тобто проявляти педагогічний такт, душевну чутливість, делікатність, терпимість, милосердя у виховній роботі 3 учнями, управляти своїми емоціями за будь-яких обставин, конструктивно взаємодіяти в групах дітей різного віку);

- діагностичні (вміння діагностувати індивідуальні особливості особистості, рівень розвитку колективу);

- проективні (вміння планувати колективну й індивідуальну роботу 3 дітьми в загоні, визначати конкретні цілі й завдання, планувати власну педагогічну діяльність);

- оцінні (вміння оцінювати результати власної виховної роботи 3 дітьми, контролювати свої дії, психічний стан, поведінку, професійні стосунки та діяльність вихованців);

- прикладні (вміння грати на музичних інструментах, танцювати, малювати, виразно декламувати тощо).

\section{VI етап. Захист практики.}

Після закінчення літньої педагогічної практики кожний студентпрактикант подає таку звітну документацію:

1. Характеристика 3 оцінкою роботи студента-практиканта, підписана керівником i завірена печаткою установи, куди він був направлений для проходження практики.

2. Звіт студента про практику в оздоровчому закладі, в якому повинно знайти відображення така інформація:

- загальні дані про роботу в закладі: місцезнаходження закладу, прізвище, ім'я, по-батькові керівника закладу, заступника керівника закладу з виховної роботи, час перебування в закладі, з дітьми якого віку працював;

- основні питання, що стосуються змісту, форм, методів роботи в закладі;

- як були використанні під час практики теоретичні знання 3 педагогіки, психології, шкільної гігієни та інших дисциплін;

- чого навчили дітей і чому навчились самі, що 3 цього, на вашу думку, може стати в нагоді для роботи в школі, житті, для роботи 3 дітьми за місцем проживання;

- 3 якими труднощами зустрілись і як їх подолали; закладі.

- висновки і пропозиції щодо поліпшення виховної роботи в

3. Щоденник загонового вожатого. 
4. План-сітка.

5. Загоновий куточок.

6. Методична розробка виховного заходу.

Після перевірки документації керівником-методистом відбувається захист практики, де студент-практикант отримує відповідну оцінку.

Таким чином, формування професійної компетенції студентів педагогічних університетів як організаторів дитячого відпочинку в умовах табірного літа включає в себе чотири основних етапи. Саме планомірне проходження кожного етапу сприяє становленню активної, творчої особистості, яка є справжнім професіоналом своєї справи.

Перспективним $\epsilon$ дослідження питань підготовки студентів до організації дозвілля дітей за різними напрямками виховання: громадянським, трудовим, естетичним, фізичним; розробки методики педагогічного керівництва самовихованням студентів 3 метою формування у них особистісних якостей; дослідження керівництва позашкільною практикою у взаємодії педагогічних закладів з оздоровчими.

\section{СПИСОК ВИКОРИСТАНИХ ДЖЕРЕЛ}

1. Гончарова Т. В. Оздоровчий заклад - центр виховної роботи з дітьми влітку / Т. В. Гончарова, Н. Я. Олійник, А. П. Тараканова // Позакласний час. - 2004. - Травень. - № 9-10. - С. 29-36.

2. Закон «Про Національну доктрину розвитку освіти» [Електронний pecypc]. - Режим доступу : http://zakon5.rada.gov.ua/laws/show/347/2002

3. Методика роботи у літньому оздоровчому таборі : навч. посіб. / [Є. І. Коваленко, А. І. Конончук, І. М. Пінчук, В. М. Солова]. - К. : I3MH, 1997. - $280 \mathrm{c}$.

4. Методичні рекомендації щодо організації літнього відпочинку дітей у 2013 році // Додаток до листа Міністерства освіти і науки України від 15.05.2013 № 1/9-321 [Електронний ресурс]. - Режим доступу : http://osvita.ua/legislation/pozashk_osv/35970/

5. Типове положення про дитячий заклад оздоровлення та відпочинку, затверджене Постановою Кабінету Міністрів України від 28 квітня 2009 року № 422 [Електронний ресурс]. - Режим доступу : http://zakon. rada.gov.ua/cgi-bin/laws/main.cgi?nreg=422-2009_\%EF 